\title{
Synthesis and application of magnetic@layered double hydroxide as an anti-inflammatory drugs nanocarrier
}

Vahid Yousefi ${ }^{1 \dagger}$, Vahideh Tarhriz ${ }^{1 \dagger}$, Shirin Eyvazi ${ }^{2}$ and Azita Dilmaghani ${ }^{3,4^{*}}$

\begin{abstract}
Background: Magnetic nanocomposites with a core-shell nanostructure have huge applications in different sciences especially in the release of the drugs, because of their exclusive physical and chemical properties. In this research, magnetic@layered double hydroxide multicore@shell nanostructure was synthesized by the facile experiment and is used as novel drug nanocarrier.

Methods: Magnetic nanospheres were synthesized by a facile one-step solvothermal route, and then, layered double hydroxide nanoflakes were prepared on the magnetic nanospheres by coprecipitation experiment. The synthesized nanostructures were characterized by FTIR, XRD, SEM, VSM, and TEM, respectively. After intercalation with Ibuprofen and Diclofenac as anti-inflammatory drugs and using exchange anion experiment, the basal spacing of synthesized layered double hydroxides was compared with brucite nanosheets from $0.48 \mathrm{~nm}$ to $2.62 \mathrm{~nm}$ and $2.22 \mathrm{~nm}$, respectively.
\end{abstract}

Results: The results indicated that Ibuprofen and Diclofenac were successfully intercalated into the interlay space of LDHs via bridging bidentate interaction. In addition, in-vitro drug release experiments in $\mathrm{pH} 7.4$, phosphate-buffered saline (PBS) showed constant release profiles with Ibuprofen and Diclofenac as model drugs with different lipophilicity, water solubility, size, and steric effect.

Conclusion: The $\mathrm{Fe}_{3} \mathrm{O}_{4} @ \mathrm{LDH}$-ibuprofen and $\mathrm{Fe}_{3} \mathrm{O}_{4} @ \mathrm{LDH}$-diclofenac had the advantage of the strong interaction between the carboxyl groups with higher trivalent cations by bridging bidentate, clarity, and high thermal stability. It is confirmed that $\mathrm{Fe}_{3} \mathrm{O}_{4} @ \mathrm{LDH}$ multicore-shell nanostructure may have potential application for constant drug delivery.

Keywords: Layered double hydroxide, Nanostructure, Iron oxide nanoparticle, Anti-inflammatory drugs, Drug delivery

\section{Background}

In recent years, magnetic nanocomposites with a coreshell nanostructure have attracted increasing attention because of their exclusive physical and chemical

*Correspondence: dilmaghani.a@gmail.com

†Vahid Yousefi and Vahideh Tarhriz contributed equally to this work and should be considered as co-first authors

${ }^{4}$ Department of Pharmaceutical Biotechnology, Faculty of Pharmacy, Tabriz University of Medical Sciences, Tabriz, Iran

Full list of author information is available at the end of the article properties and huge possible applications in different areas such as extraction, the release of drug, medicine, mechanical aspects, etc. [1-5]. Several performanceparticulars with high surface shells have been prepared so far on the iron oxide nanospheres, significantly growing the magnetic core@shell nanostructure area [6-8]. Inorganic nanomaterials are commonly used because of their low cost, high surface area, easy availability, and easy preparation. Layered double hydroxides (LDHs),

c) The Author(s) 2020. This article is licensed under a Creative Commons Attribution 4.0 International License, which permits use, sharing, adaptation, distribution and reproduction in any medium or format, as long as you give appropriate credit to the original author(s) and the source, provide a link to the Creative Commons licence, and indicate if changes were made. The images or other third party material in this article are included in the article's Creative Commons licence, unless indicated otherwise in a credit line to the material. If material is not included in the article's Creative Commons licence and your intended use is not permitted by statutory regulation or exceeds the permitted use, you will need to obtain permission directly from the copyright holder. To view a copy of this licence, visit http://creativecommons.org/licenses/by/4.0/. The Creative Commons Public Domain Dedication waiver (http://creativecommons.org/publicdomain/zero/1.0/) applies to the data made available in this article, unless otherwise stated in a credit line to the data. 
recognized as anionic clays or brucite-like compounds, are two important sub-classes of ionic layered materials. LDHs are represented with the general formula of $\left[\mathrm{M}(\mathrm{II})_{1-\mathrm{x}} \mathrm{M}(\mathrm{III})_{\mathrm{x}} \cdot(\mathrm{OH})_{2}\right]^{\mathrm{x}+}\left[\mathrm{A}^{\mathrm{n}-}\right]_{\mathrm{x} / \mathrm{n}} \cdot \mathrm{mH}_{2} \mathrm{O}$, where $\mathrm{M}^{2+}$ and $\mathrm{M}^{3+}$ are respectively di- and trivalent metal cations, and $\mathrm{A}$ is $\mathrm{n}$-valent interlayer guest anion. The primary constituents of LDHs are the charged layers that provide diverse chemical compounds with versatile usability, for example, biocompatibility, adsorption, intercalation, and ion exchange [9-11]. These are the bases of LDHs diverse technology applications in a variety of fields including medicine, polymer industries, electrochemistry, food, catalysis, drug delivery separation, and more. In comparison to other drug delivery mechanisms, which show low circulation stability, poor bioavailability, and drug degradation, LDH as exquisite drug nano-carriers are comparatively economical with little toxicity for the cells and biocompatibility [12]. Moreover, ease of production and large capacity for affective drug transportation make them ideal nano-carreirs [10]. Even so, layered double hydroxide nanoparticles are easily aggregated in phosphate buffered saline solution that reduces the number of proper sized nanoparticles available for internalization and, as a result, affect the delivery efficiency [13]. To overcome the current disadvantage, designing and application of anti-aggregation materials such as nanostructure that exploit porosity and high surface are an urgent demand, offering limited control over the morphology, surface area, and particles size that powerfully define the practical performances. Additionally, the achievements of previous studies in this scope encouraged us to use LDH nanostructures, as a suitable drug carrier. LDHs also protect the cargo from environmental modifications and degradation. In addition, they enhance the loading capacity, stability, and penetration aptitude of the cargoes [11, 14]. Some studies have indicated that LDHs are simply aggregated in a phosphate-buffered solution (PBS), decreasing the number of properly sized LDHs available for internalization and improving the efficiency of delivery [14]. Likewise, LDHs are able to infiltrate into the cells and stabilize the drugs and biomolecules within the interlayer. Consequently, as excellent preserving molecules, LDHs protect the loaded molecules from damage, degradation, and alternation and also enhance the loading density, chemicophysical stability, and penetration ability of the loaded drug [15-17]. On the other hand, LDHs containing magnesium and aluminum have already been used as an antacid and antipepsin agent; hence, LDH is quite biocompatible.

In order to pass through the current drawbacks, designing and synthesis of anti-aggregation compounds such as nanostructures that utilize porosity and high surface are an instant demand. The nanostructures should propose restricted control over the morphology, pore architectures, surface area, and particles size that strongly explain the practical performances. Importantly, LDHs carry magnesium and aluminum to display antacid and antipepsin function; therefore, LDH is identified as a fully biocompatible combination. Accordingly, in this research, $\mathrm{Fe}_{3} \mathrm{O}_{4} @ \mathrm{LDH}$ multicore@shell nanostructure was synthesized by the facile experiment and used as a novel drug nanocarrier. The carriers were characterized using XRD, FT-IR, TEM, VSM, and SEM in order to display chemical structure and morphology.

\section{Materials and methods}

\section{Materials and reagents}

Iron(III) chloride, ethylene glycol, magnesium nitrate hexahydrate, ammonium acetate, aluminum nitrate nonahydrate, and all solvents were purchased from the Sigma-Aldrich or Merck companies.

\section{Synthesis of uniform-size $\mathrm{Fe}_{3} \mathrm{O}_{4}$ nanospheres}

$8 \mathrm{mmol}$ Iron(III) chloride was dissolved in ethylene glycol $(45 \mathrm{~mL})$, and then, $45 \mathrm{mmol}$ of ammonium acetate was added under rapid stirring. Afterwards, the resulting mixture was solvothermal treated at $190{ }^{\circ} \mathrm{C}$ for $8 \mathrm{~h}$. Before collecting the powder via centrifugation, it was washed and dried at $70^{\circ} \mathrm{C}$ overnight.

\section{In-situ synthesis of $\mathrm{Fe}_{3} \mathrm{O}_{4} @ L D H$ multicore@shell nanostructure}

The experimental procedure for the preparation of layered double hydroxide nanoflake on $\mathrm{Fe}_{3} \mathrm{O}_{4}$ was similar to that described in the literature. Briefly, $0.3 \mathrm{~g}$ of the synthesized $\mathrm{Fe}_{3} \mathrm{O}_{4}$ nanoparticles was spread into $200 \mathrm{ml}$ water and methanol (1:1), ultrasonically agitating for 20 min to achieve a homogeneous suspension. Then, a $200 \mathrm{ml}$ solution made of $2.6 \mathrm{~g}$ of sodium carbonate and $3.2 \mathrm{~g}$ sodium hydroxide in water and methanol solution (1:1) were added into the solution until $\mathrm{pH}=10$ was obtained. Formerly, $200 \mathrm{ml}$ water and methanol solution (1:1) containing $2.25 \mathrm{~g}$ aluminum nitrate nonahydrate and $2.6 \mathrm{~g}$ magnesium nitrate hexahydrate were added to the prepared suspension by controlling and maintaining $\mathrm{pH}$ at 10 through the addition of an alkaline solution simultaneously. The semiliquid mixture was aged at $70{ }^{\circ} \mathrm{C}$ overnight. The product was isolated using an external magnet, and the precipitate was rinsed three times with water and ethanol and then dried in an oven at $70{ }^{\circ} \mathrm{C}$ for $12 \mathrm{~h}$. Finally, to load each drug, $3 \mathrm{~g}$ of synthesized-nanostructure was immersed in $100 \mathrm{ml}$ distilled water containing $3 \mathrm{~g}$ of the desired drug (Ibuprofen and Diclofenac) and $1 \mathrm{~g}$ of potassium hydroxide with $\mathrm{pH}$ control at 9 at room temperature for $24 \mathrm{~h} \mathrm{[18].}$ 


\section{Drug release from drug-containing $\mathrm{Fe}_{3} \mathrm{O}_{4} @ L D H$ multicore@ shell nanostructure}

The drug-containing $\mathrm{Fe}_{3} \mathrm{O}_{4} @ \mathrm{LDH}$ multicore@shell nanostructures $(0.2 \mathrm{~g})$ were blended with $100 \mathrm{ml}$ of PBS at $120 \mathrm{rpm}, \mathrm{pH} 7.4$, and $37^{\circ} \mathrm{C}$. About $5 \mathrm{ml}$ of solution was disposed and immediately changed with an equal volume of fresh PBS at the same time intervals for keeping the volume constant. The uninvolved solution was centrifuged to remove the $\mathrm{Fe}_{3} \mathrm{O}_{4} @ \mathrm{LDH}$ multicore@shell nanostructures and correctly diluted before the measurement of Ibuprofen and Diclofenac released absorbance via UVvis spectrophotometer at $264 \mathrm{~nm}$ and $276 \mathrm{~nm}$, respectively; the amount released was calculated by means of a standard curve (Additional file 1: Figs. S1 and S2).

\section{Characterization}

FT-IR spectra of the materials were written down over the range of $400-4000 \mathrm{~cm}^{-1}$ regions using a Bruker Tensor 27 series FT-IR spectrometer. Powder X-ray diffraction patterns of the samples were recorded in the range of $2^{\circ}-70^{\circ}$ on a Siemens D5000 X-ray Diffractometer, using $\mathrm{CuK} \alpha$ radiation $(\lambda=1.5418 \AA$ ) at $30 \mathrm{kV}$ and $30 \mathrm{~mA}$. The morphology of the nanomaterial specimens was observed using the SEM (MIRA3-TESCAN) and transmission electron microscope (Philips CM30). The rate of the absorbance of the drugs was measured by UV-vis spectroscopy (UV-1700 Pharma Spec, Shimadzu).

\section{Antibacterial assays of $\mathrm{Fe}_{3} \mathrm{O}_{4} @ L D H$}

For testing the antimicrobial feature of $\mathrm{Fe}_{3} \mathrm{O}_{4} @ \mathrm{LDH}$ multicore-shell nanostructure, the gram positive bacterium "Bacillus cereus strain ATCC11778 ${ }^{\mathrm{T}}$ " and the gram negative bacteria including Escherichia coli strain $\mathrm{O}_{157^{\mathrm{T}}}$ and Klebsiella pneumonia strain PTCC10031 ${ }^{\mathrm{T}}$ were chosen as the human pathogenic microorganisms for antibacterial activity test. About $250 \mu \mathrm{g} / \mathrm{ml}$ of Fe3O4@LDH was added into $6 \mathrm{~cm}$ wells in the Mueller Hinton Agar plates. Then, 0.5 McFarland standard $\left(10^{8} \mathrm{cfu} / \mathrm{ml}\right)$ of the bacteria suspensions was prepared by dilution in Mueller Hinton Broth and slightly spread on the plates. The plates were incubated at $37^{\circ} \mathrm{C}$ for $24 \mathrm{~h}$. Methanol solvent $(100 \mu \mathrm{g} / \mathrm{ml})$ was used as negative control. Each experiment was performed in triplicate, and the diameter of the inhibition zones was measured and calculated [19].

\section{Cytotoxicity assays of $\mathrm{Fe}_{3} \mathrm{O}_{4} @ L D H$}

For testing the cytotoxicity of $\mathrm{Fe}_{3} \mathrm{O}_{4} @ \mathrm{LDH}$ on eukaryotic cells, MTT assays were performed to measure cell viability in the presence of the nanoparticles. Immortalized mouse myoblast cells ( $\mathrm{C} 2 \mathrm{C} 12$ cells) were seeded at a density of $0.5 \times 10^{4}$ cells per well in $200 \mathrm{ml}$ Dulbecco's modified eagle (DMEM) medium $+10 \%$ fetal bovine serum (FBS) with two different concentrations (0.001 and
$0.005 \mathrm{~g})$ of $\mathrm{Fe}_{3} \mathrm{O}_{4} @ \mathrm{LDH}$ in 96 well plates. After incubation for $48 \mathrm{~h}$, the media were replaced with fresh culture media containing MTT solution $(0.5 \mathrm{mg} / \mathrm{ml})$, and the cells were incubated for an additional $4 \mathrm{~h}$ at $37{ }^{\circ} \mathrm{C}$. The absorbance was measured at $570 \mathrm{~nm}$ using a spectrophotometric microplate reader (Biotek, EL $\times 800$ ) [20]. The cells were seeded without nanoparticles as a positive control, and DMSO treated cells were tested as a negative control. One-way ANOVA by graphpad prism \pm S.E.M. at $\mathrm{P}$-value $<0.05$ was used for data analysis [18].

\section{Results and discussion}

The $\mathrm{Fe}_{3} \mathrm{O}_{4} @ \mathrm{LDH}$ multicore-shell nanostructure was synthesized in two steps: firstly, magnetite nanoparticles were synthesized by solvothermal and Ostwald ripening method, and then layered double hydroxide nanoflakes were prepared on the magnetic nanoparticles by in-situ coprecipitation method and used as the new nanocarrier. Ethylene glycol was used for three reasons: solvent, reduction agent of $\mathrm{Fe}^{3+}$ to $\mathrm{Fe}^{2+}$, and synthesis of nanoparticles with monodisperse nanoparticles [21].

\section{Characterization of synthesized nanomaterials}

Figure 1 depicts the schematic of the synthesis of $\mathrm{Fe}_{3} \mathrm{O}_{4} @$ LDH multicore@shell nanostructure. Figure 2 confirms and demonstrates surface morphologies and also determines particle sizes of (a) $\mathrm{Fe}_{3} \mathrm{O}_{4}$ nanospheres, (b) $\mathrm{Fe}_{3} \mathrm{O}_{4} @$ LDH multicore-shell nanostructure, and (c) $\mathrm{Fe}_{3} \mathrm{O}_{4} @$ LDH-ibuprofen. Figure 2a, b obviously display the monodisperse structure of $\mathrm{Fe}_{3} \mathrm{O}_{4}$ nanospheres and $\mathrm{Fe}_{3} \mathrm{O}_{4} @$ $\mathrm{LDH}$ multicore-shell nanostructure. The diameter of the $\mathrm{Fe}_{3} \mathrm{O}_{4}$ nanostructure is determined $80-130 \mathrm{~nm}$, and the thickness of the LDH nanoflakes shell is about 70-110 nm (Fig. 2d). Furthermore, the $\mathrm{Fe}_{3} \mathrm{O}_{4} @ \mathrm{LDH}-\mathrm{ibu}-$ profen, has a morphology, even after loading of drug into the LDH layer structure (Fig. 2c).

The TEM was used to prove the core-shell structures and to show the porous and multicore nanoparticles created by the Ostwald ripening method. This method leads to formation of magnetic sphere particles in selfassembly form from smaller particles. According to the obtained TEM image, the size of core-forming nanoparticles is $10-13 \mathrm{~nm}$ and the size of magnetic spheres is approximately $80-130 \mathrm{~nm}$. With regard to (Fig. 3a) $\mathrm{Fe}_{3} \mathrm{O}_{4} @ \mathrm{LDH}$ multicore-shell nanostructure and (Fig. 3b) $\mathrm{Fe}_{3} \mathrm{O}_{4} @ \mathrm{LDH}$-ibuprofen, as the drug-loading nanostructure. Figure $3 \mathrm{~b}$ confirms that the multicore and coreshell structure of nanoparticles are completely stable after loading of the drug.

The Fourier transform infrared spectra of (a) $\mathrm{Fe}_{3} \mathrm{O}_{4}$ nanospheres, (b) $\mathrm{Fe}_{3} \mathrm{O}_{4} @ \mathrm{LDH}$ multicore-shell nanostructure, (c) $\mathrm{Fe}_{3} \mathrm{O}_{4} @ \mathrm{LDH}$-ibuprofen, and (d) $\mathrm{Fe}_{3} \mathrm{O}_{4} @$ LDH-diclofenac are shown in Fig. 4. The FT-IR spectra 
of $\mathrm{Fe}_{3} \mathrm{O}_{4}$ nanospheres (Fig. 4a), two highest peaks linked to metal-oxygen bonds, were observed. The first band detected in the range of $385-540 \mathrm{~cm}^{-1}$ is normally apportioned to octahedral-metal stretching, whereas the highest one detected in the $500-600 \mathrm{~cm}^{-1}$ range is consistent with basic stretching vibrations of the metal at the tetrahedral site. The higher frequency band at $574 \mathrm{~cm}^{-1}$ and lower frequency band at $448 \mathrm{~cm}^{-1}$ are assigned to the tetrahedral and octahedral, respectively. Additionally, the peak at $\sim 3360 \mathrm{~cm}^{-1}$ is attributed to the stretching vibrations of hydroxyl allocated to hydroxyl absorbed by magnetic nanospheres, and the existence of water is evidenced by the appearance of the bending mode at $1645 \mathrm{~cm}^{-1}$ and the stretching mode at $3476 \mathrm{~cm}^{-1}$. Compared with the spectrum of $\mathrm{Fe}_{3} \mathrm{O}_{4} @ \mathrm{LDH}$ multicore-shell nanostructure with $\mathrm{Fe}_{3} \mathrm{O}_{4} @ \mathrm{LDH}$-ibuprofen and $\mathrm{Fe}_{3} \mathrm{O}_{4} @$ LDH-diclofenac, there are particular similar peaks in their spectra (Fig. 4c, d). The principal peaks were between 2800 and $3000 \mathrm{~cm}^{-1}$ due to the alkyl stretching of drugs, especially in Ibuprofen due to the existence of many methyl groups in its structure compared with Diclofenac. Two peaks also appeared at approximately 1421 and $1576 \mathrm{~cm}^{-1}$, recognized to the symmetric and asymmetric stretch of the carboxyl group, respectively. The interaction between the metal atom and the carboxylate groups was classified into three types: monodentate, bridging, and chelating [22, 23]; the major difference $\left(200-320 \mathrm{~cm}^{-1}\right)$ was related to the monodentate interaction, and the lowest difference $\left(<110 \mathrm{~cm}^{-1}\right)$ was for the chelating bidentate. The medium-range difference (140$\left.190 \mathrm{~cm}^{-1}\right)$ was for the bridging bidentate. The $\Delta(1576-$ $1421=155 \mathrm{~cm}^{-1}$ ) was ascribed as bridging bidentate. Moreover, the peaks at 1440 and $1519 \mathrm{~cm}^{-1}$ are related to $\mathrm{C}-\mathrm{C}$ stretching vibration in benzene rings. These outcomes provided subsequent assistance that Ibuprofen and Diclofenac have been loaded into the layered double hydroxide nanoflakes in the anionic form.

The XRD patterns of the $\mathrm{Fe}_{3} \mathrm{O}_{4}$ nanospheres (Fig. 5a) in the $2 \theta$ range of $2-70^{\circ}$ are shown in Fig. 5. Besides, with loading the drugs, the regenerated matrix indicates representative diffraction peaks of the LDH-drugs, representing two sharp basal reflections indexed as (003) and (006) reflections in line with the well-crystallized lamellar construction in synthesized nanocarrier with $3 \mathrm{R}$ rhombic proportion. The important diffraction peaks of $\mathrm{Fe}_{3} \mathrm{O}_{4} @$ LDH-ibuprofen (Fig. 5b) and $\mathrm{Fe}_{3} \mathrm{O}_{4} @ \mathrm{LDH}$-diclofenac (Fig. 5c) are achieved at $2 \theta$ value of $7.6^{\circ}$ and $7.8^{\circ}$. The $\mathrm{d}_{003}$ spacing of $\mathrm{Fe}_{3} \mathrm{O}_{4} @ \mathrm{LDH}$-ibuprofen and $\mathrm{Fe}_{3} \mathrm{O}_{4} @$ $\mathrm{LDH}$-diclofenac were found to be $2.62 \mathrm{~nm}$ and $2.22 \mathrm{~nm}$, respectively.

The magnetic properties of magnetic nanospheres (Fig. 6a) and $\mathrm{Fe}_{3} \mathrm{O}_{4} @ \mathrm{LDH}$ multicore-shell nanostructure (Fig. 6b) were specified using a vibrating sample magnetometer (VSM). The magnetic saturation values of the magnetic nanospheres and $\mathrm{Fe}_{3} \mathrm{O}_{4} @ \mathrm{LDH}$ multicore-shell nanostructure were 59 and $32 \mathrm{emu} / \mathrm{g}$, respectively. After the LDH shell packing of $\mathrm{Fe}_{3} \mathrm{O}_{4}$ (curve (b)), the saturated magnetization of the $\mathrm{Fe}_{3} \mathrm{O}_{4} @ \mathrm{LDH}$ multicore-shell

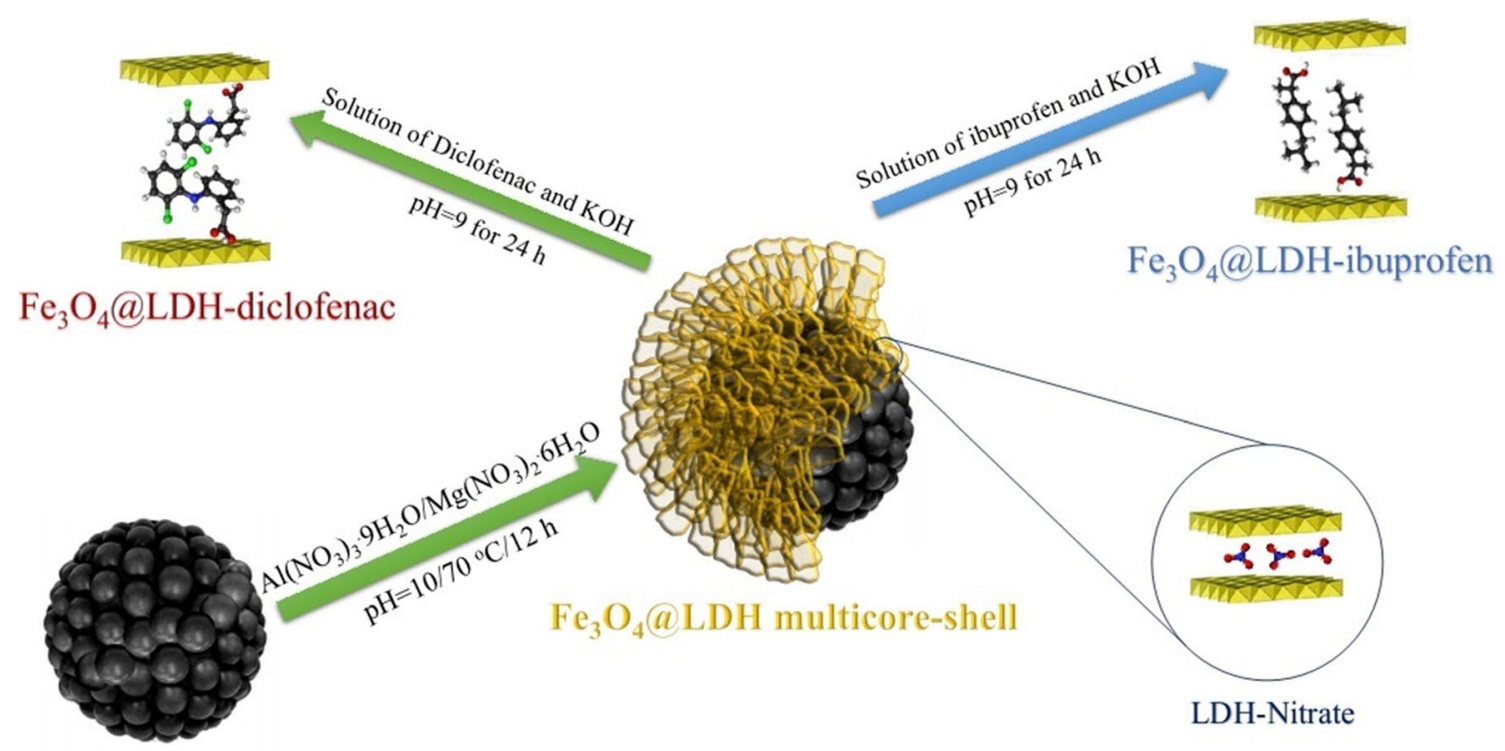

$\mathrm{Fe}_{3} \mathrm{O}_{4}$ nanospheres

Fig. 1 Schematic representation of preparation of $\mathrm{Fe}_{3} \mathrm{O}_{4} @ \mathrm{LDH}$ multicore-shell nanostructure before and after the intercalation of the anti-inflammatory drugs 

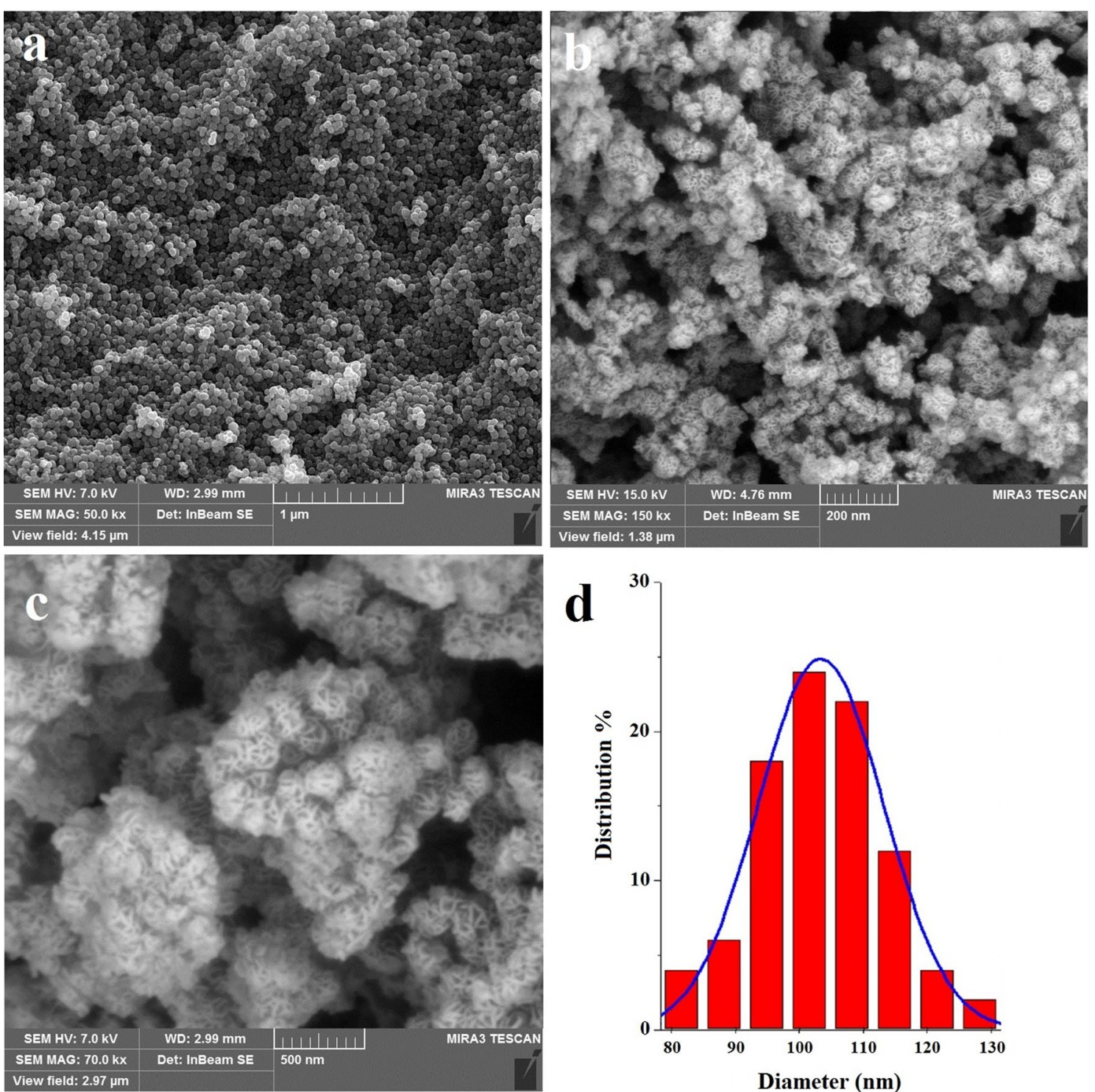

Fig. 2 The SEM images of $\mathbf{a} \mathrm{Fe}_{3} \mathrm{O}_{4}$ nanospheres and $\mathbf{b} \mathrm{Fe}_{3} \mathrm{O}_{4} @ \mathrm{LDH}$ multicore-shell nanostructure, $\mathbf{c} \mathrm{Fe}_{3} \mathrm{O}_{4} @ \mathrm{LDH}$-ibuprofen and $\mathbf{d}$ the diameter of the $\mathrm{Fe}_{3} \mathrm{O}_{4}$ nanospheres

nanostructure decreases because of the shield of the LDH nanoflakes.

Inhibition zones for the two pathogen bacteria including Bacillus cereus strain ATCC $11778^{\mathrm{T}}$ (Fig. 7a) and Klebsiella pneumonia strain PTCC10031 ${ }^{\mathrm{T}}$ (Fig. 7b) were observed in the presence of the nanoparticles. Most nanoparticles and nanostructures exert their antibacterial properties with different mechanisms such as destruction of bacterial membranes, inhibition of biofilm formation, or other multiple mechanisms [24], indicating that the nanoparticle has antimicrobial feature which can be considered as an extra benefit for drug delivery.
MTT assay analysis showed that $\mathrm{Fe}_{3} \mathrm{O}_{4} @ \mathrm{LDH}$ multicore-shell nanostructure in $0.001 \mathrm{~g}$ concentration had a less negative effect on $\mathrm{C} 2 \mathrm{C} 12$ cells as upon $90 \%$ of the cells treated viable in comparison to the control group (Fig. 8). The non-toxicity of nanoparticle can be considered a positive point for using them in drug delivery to eukaryotic organisms, especially humans. In addition, no valuable difference has been observed between 0.001 and $0.005 \mathrm{~g}$ concentrations of $\mathrm{Fe}_{3} \mathrm{O}_{4} @ \mathrm{LDH}$ on cell viability. However, it was observed that the viability of about $20-30 \%$ of cells decreases in the presence of the high concentration of the nanostructure $(0.05$ and $0.01 \mathrm{~g})$. 

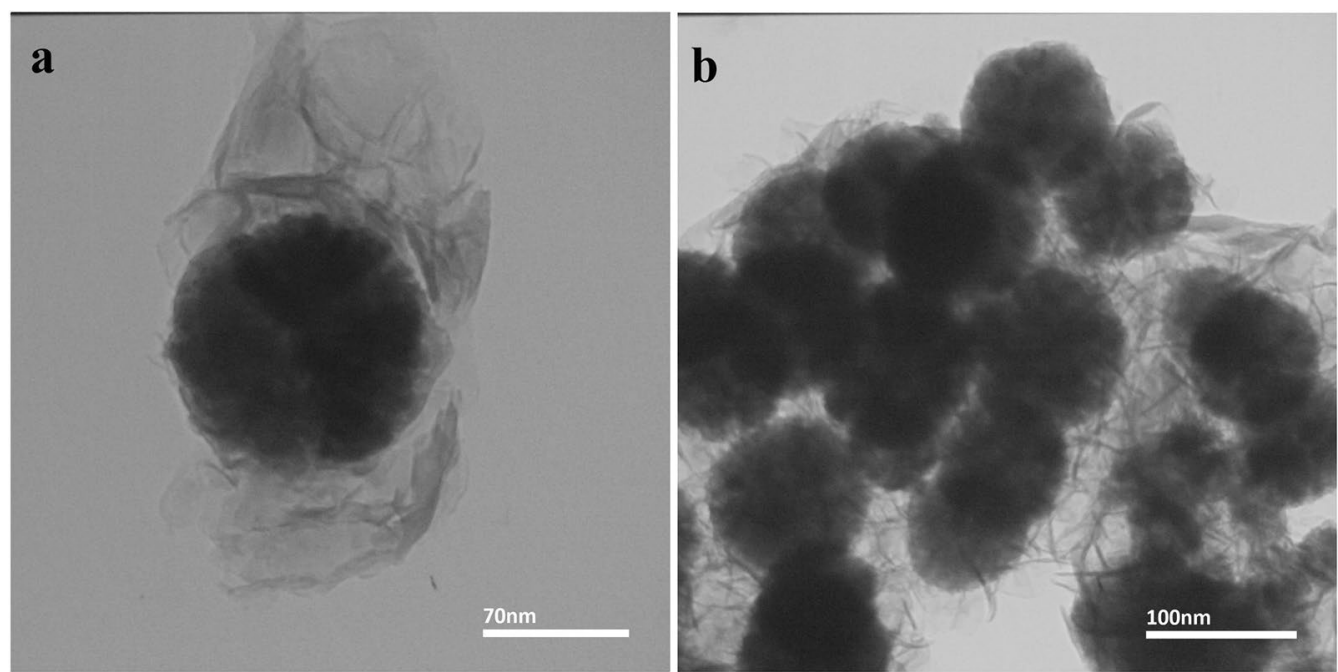

Fig. 3 The TEM image of $\mathbf{a} \mathrm{Fe}_{3} \mathrm{O}_{4} @ \mathrm{LDH}$ multicore-shell nanostructure and $\mathbf{b} \mathrm{Fe}_{3} \mathrm{O}_{4} @ \mathrm{LDH}$-ibuprofen, as the drug-loading nanostructure. The multicore, and core-shell structure of nanoparticles is stable completely after loading of the drug

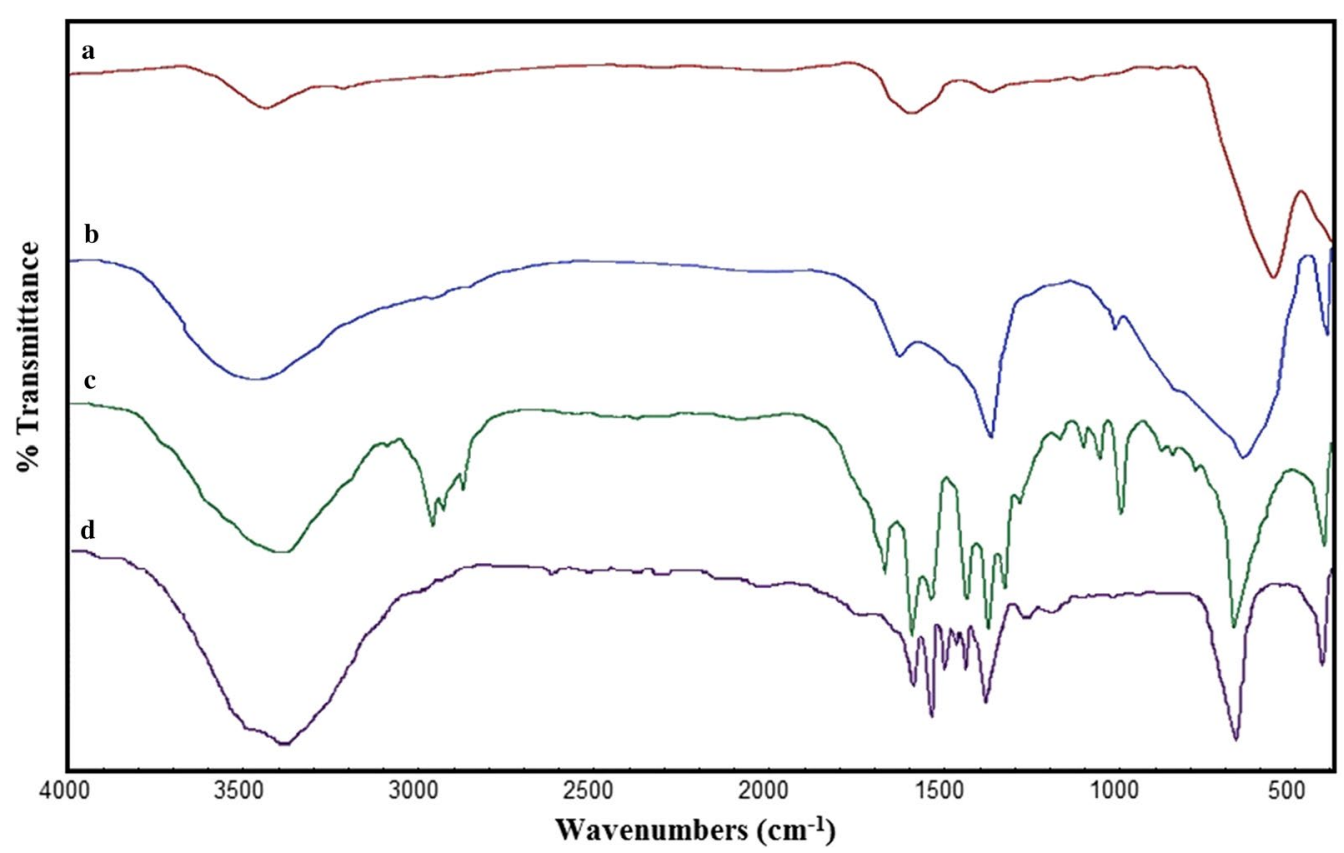

Fig. 4 FT-IR spectra of $\mathbf{a ~} \mathrm{Fe}_{3} \mathrm{O}_{4}$ nanospheres, b Fe $\mathrm{O}_{4} @ \mathrm{LDH}$ multicore-shell nanostructure, $\mathbf{c} \mathrm{Fe}_{3} \mathrm{O}_{4} @ \mathrm{LDH}$-ibuprofen and $\mathbf{d} \mathrm{Fe}_{3} \mathrm{O}_{4} @ \mathrm{LDH}$-diclofenac

Based on the literature, the nanoparticle size plays an important role in cellular uptake and intracellular trafficking of drug encapsulated in LDH nanoparticles. Several studies have demonstrated that FITC-LDHs are internalized into cells through the clathrin-mediated endocytosis [25]. However, it has been noticed that the mechanism of selectively permeating into cell is effective only at LDH nanoparticle size of $300 \mathrm{~nm}$ or less [26].
As the size of $\mathrm{Fe}_{3} \mathrm{O}_{4} @ \mathrm{LDH}$ nanoparticles is $80-130 \mathrm{~nm}$, probably these nanoparticles penetrate into $\mathrm{C} 2 \mathrm{C} 12$ cell via selectively clathrin-mediated endocytosis.

UV-Vis spectrum of Ibuprofen and Diclofenac release assay Drug release is specified as the speed of mass transport from a solid phase into the broth media under normal conditions. The major phase in drug delivery is an 
interaction between the drug carrier and PBS $(\mathrm{pH}=7.4)$ that happens at the interface of carrier and buffer solution, and absorption was measured via UV-Vis Spectrophotometer in specified intervals. According to the previous studies, the suitable $\mathrm{pH}$ for releasing drug in oral nanoparticles is in physiological buffers condition (pH 7.4) [27]. Each segment of the gastrointestinal (GI) tract maintains its own characteristic $\mathrm{pH}$ level from the acidic stomach lumen ( $\mathrm{pH} \mathrm{1-3)} \mathrm{for} \mathrm{digestion} \mathrm{to} \mathrm{the} \mathrm{alka-}$ line duodenum and ileum $(\mathrm{pH}$ 6.6-7.5) for the neutralization of chyme. Oral nanoparticles retain a hydrophobic and collapsed state in the stomach due to the protonation of hydroxyl groups and increase the zeta potential. After gastric passage, an increase in $\mathrm{pH}$ leads to activation of nanoparticles due to decrease of zeta potential and hydrogen bond breakage of interlayers of LDH [2730]. It should be noted that Ibuprofen and Diclofenac are weak acids that are not be soluble in acidic media, but should be soluble at $\mathrm{pH}$ higher than 6.8 [31-33]. Moreover, at a $\mathrm{pH}$ above 9 , the increase in the concentration of competing $\mathrm{OH}^{-}$anions is responsible for the observed decrease in the recovery [33]; over $~ 90 \%$ of the drugs are released at $\mathrm{pH} 7.4$ in the first several hours. Designed nanoparticles for oral drug delivery such as our nanoparticle undergo a surface charge reversal and decrease zeta potential after gastric passage, hoping that drug release will possibly occur in the alkaline intestinal tract instead. Using our inorganic materials with different densities of positively-charged facilitated loading and trapping of anionic drugs such as Ibuprofen (an anti-inflammatory prodrug for bowel disease) in acidic environments $(\mathrm{pH}<3)$. When the drug-loaded nanoparticles were placed in physiological buffers $(\mathrm{pH} 7.4)$, a partial negative surface charge on the nanoparticle was generated; this electrostatic repulsion triggered the sustained release of loaded drugs. According to the previous studies, the release assays were, hence, carried out in physiological buffers condition ( $\mathrm{pH} 7.4)[10,18]$ at $37^{\circ} \mathrm{C}$ which is similar to the normal body temperature.

Figure 9 illustrates that the drug release occurred at intervals within $15 \mathrm{~min}$ to $72 \mathrm{~h}$ in the wavelength of $264 \mathrm{~nm}$ for Ibuprofen and wavelength of $276 \mathrm{~nm}$ for Diclofenac. Both drug releases gently increased within $15 \mathrm{~min}$ to $6 \mathrm{~h}$ interval, and the concentration of drug was fixed within $6 \mathrm{~h}$ to $72 \mathrm{~h}$ interval. The release rate of Ibuprofen was $90 \%$ within $24 \mathrm{~h}, 94 \%$ in $48 \mathrm{~h}$, and $96 \%$ in $72 \mathrm{~h}$. The values for Diclofenac in $24 \mathrm{~h} 78 \%$, within $48 \mathrm{~h}$ of $81 \%$ in $72 \mathrm{~h}$ and $82 \%$, respectively, indicating less Diclofenac release in comparison to Ibuprofen per unit of time. This can be due to lower solubility in water [34], highly lipophilicity [35] of Diclofenac, small size, and more sterile effect of Diclofenac compared to Ibuprofen [36] that cannot be easily released between layers. The release gradually arrived the maximum amount of $90 \%$ for Ibuprofen and $78 \%$ for Diclofenac in the first $6 \mathrm{~h}$. On the other hand, the most absorbed drug in the outer layer of the $\mathrm{Fe}_{3} \mathrm{O}_{4} @$ $\mathrm{LDH}$ and bonded drug to the substrate by its hydrogen bonds release in the $24 \mathrm{~h}$ especially in first $6 \mathrm{~h}$ which is useful for quickly developing as a therapeutic dose. Other remaining drugs in the structure less than $10 \%$

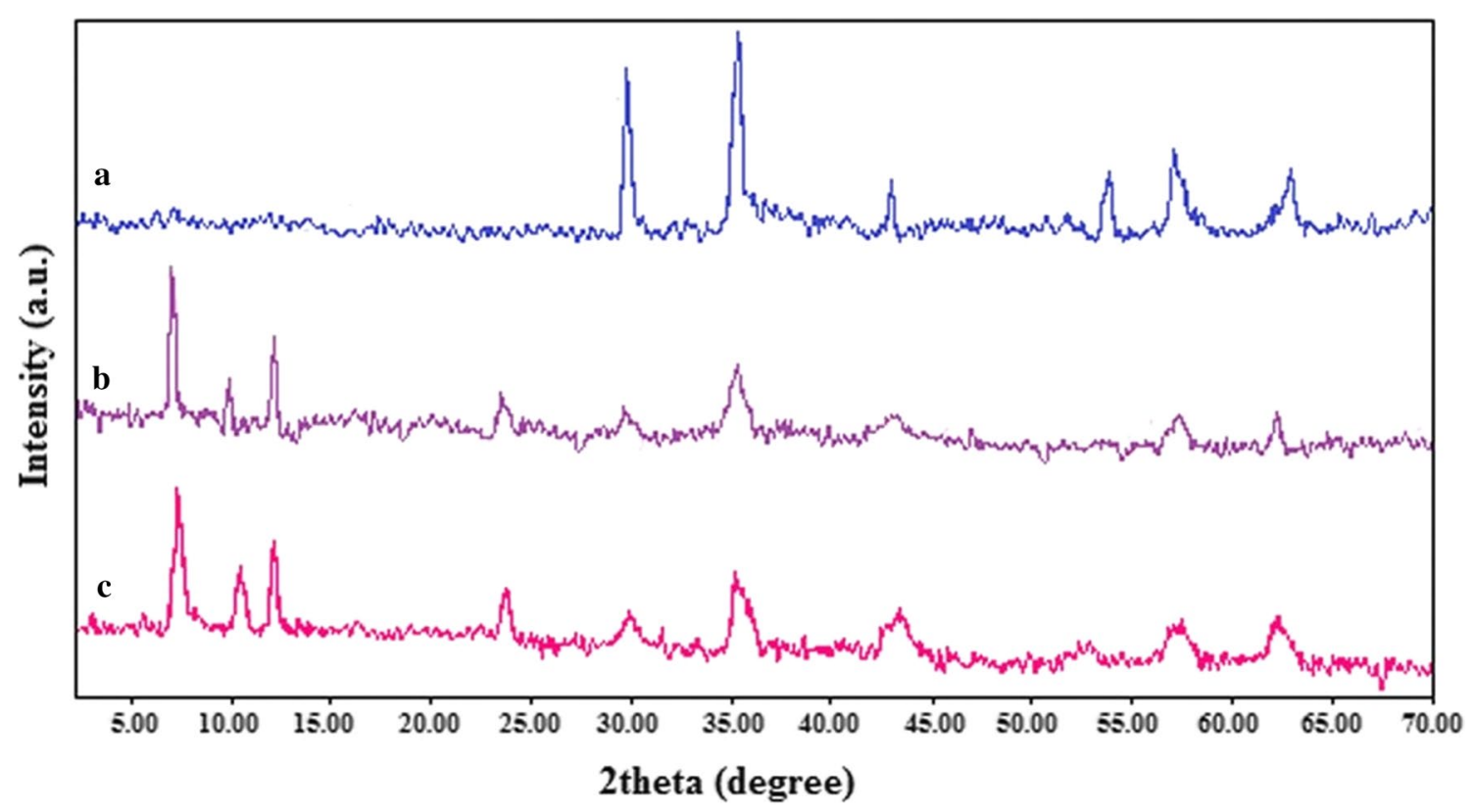

Fig. 5 The XRD powder diffraction patterns of $\mathbf{a ~} \mathrm{Fe}_{3} \mathrm{O}_{4}$ nanospheres, b Fe $\mathrm{O}_{4} @ \mathrm{LDH}$-ibuprofen, $\mathbf{c} \mathrm{Fe}_{3} \mathrm{O}_{4} @ \mathrm{LDH}$-diclofenac 


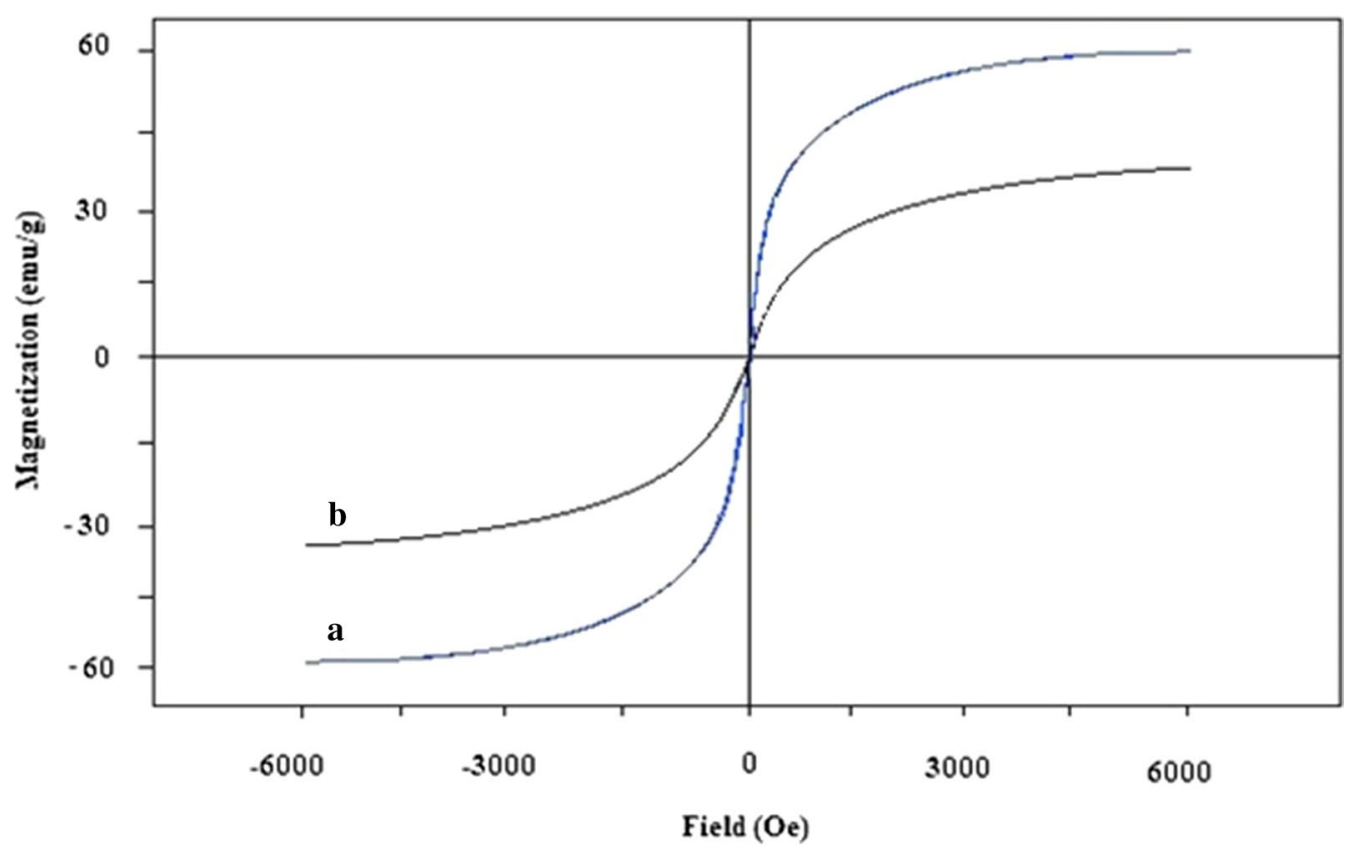

Fig. 6 The VSM curves of $\mathbf{a} \mathrm{Fe}_{3} \mathrm{O}_{4}$ nanospheres and $\mathbf{b} \mathrm{Fe}_{3} \mathrm{O}_{4} @ \mathrm{LDH}$ multicore-shell nanostructure
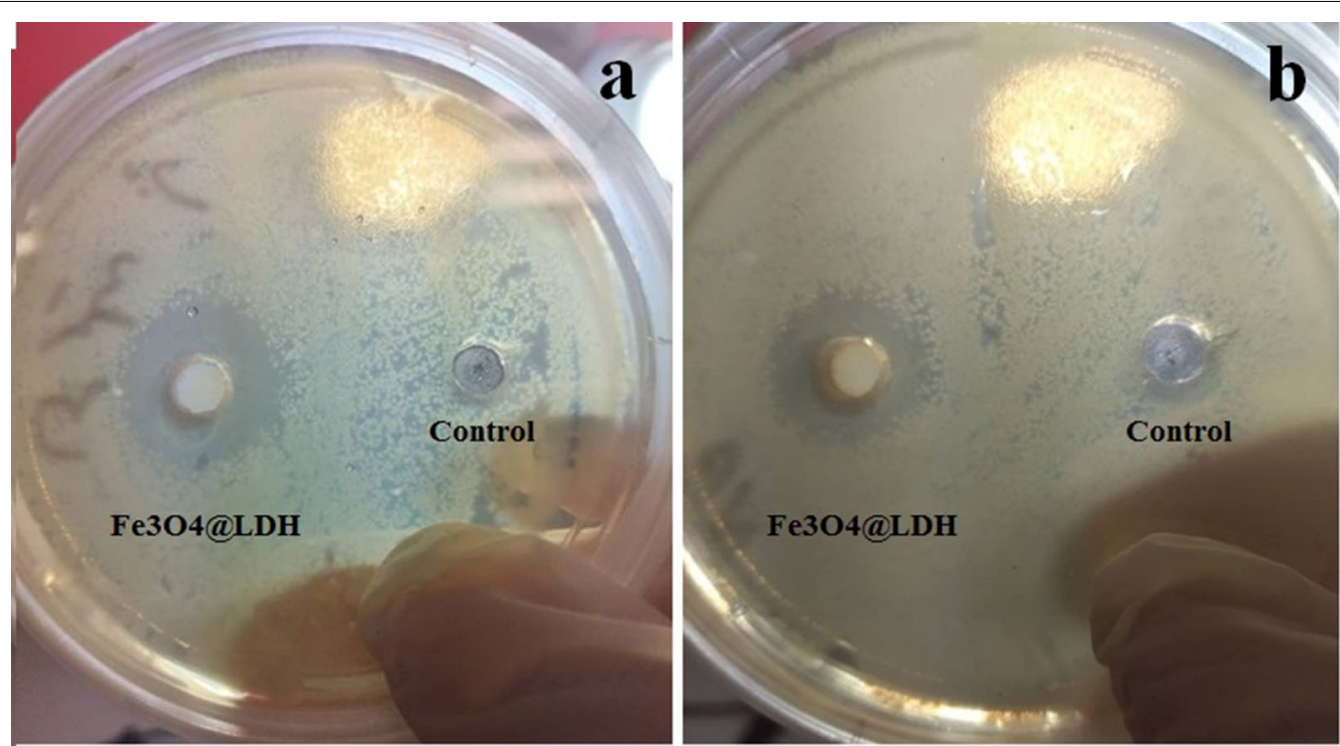

Fig. 7 The antagonistic effect of concentrated bacterial cell free culture medium on the growth of a Bacillus cereus strain ATCC11778 ${ }^{\top} \mathbf{b}$ Klebsiella pneumonia strain PTCC $10031^{\top}$

for Ibuprofen and $20 \%$ for Diclofenac which were in the interlayers of the LDH release slowly. The slower delivery rate can be utilized as a therapeutic dose in longer time for decreasing the number of doses required. The cumulative release kinetic of Ibuprofen and Diclofenac from $\mathrm{Fe}_{3} \mathrm{O}_{4} @ \mathrm{LDH}$ nanostructure in phosphate buffer saline (PBS) at $\mathrm{pH}=7.4$ showed a sustained release of up to $72 \mathrm{~h}$ that closely resembled first order release kinetics through a combination of drug diffusion and dissolution of LDH under physiological conditions (Additional file 1: Fig. S3).

Drug loading between LDH layers leads to different release rates of drug and enhances the solubility of the 

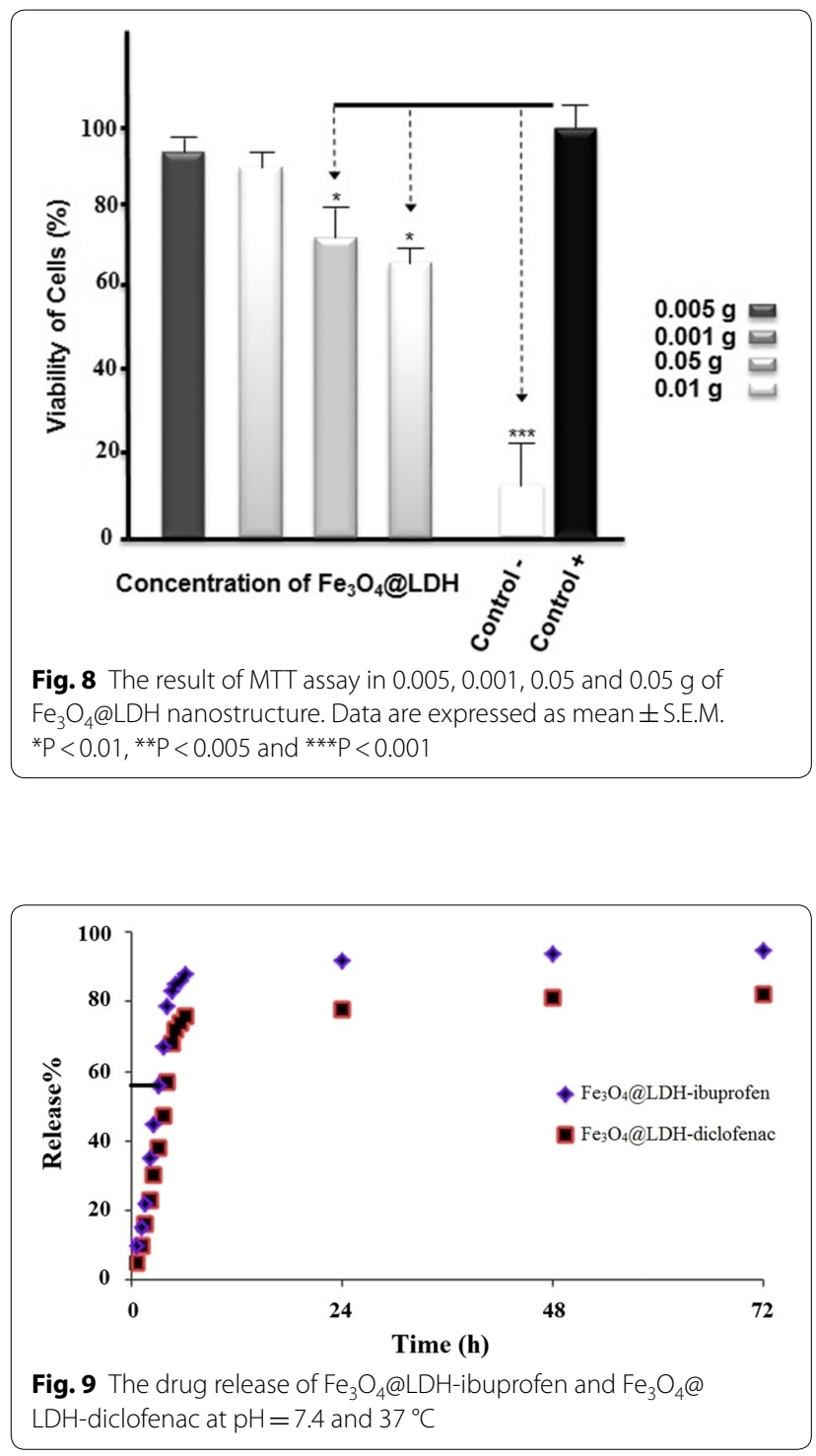

drug and also, reduces its side effects, compared with old and industrial methods.

As other anionic drugs, it seems that the drug release mechanism of Diclofenac and Ibuprofen from the LDH nanoparticles is probably surface diffusion and bulk diffusion via anionic exchange of the drugs anions on, or in, the LDHs with anions in the PBS solution [37]. $\mathrm{Fe}_{3} \mathrm{O}_{4} /$ LDHs nanocomposites have been also noticed for drug delivery in different studies due to their layered structure and unique properties [38]. Komarala et al. developed $\mathrm{LDH}-\mathrm{Fe}_{3} \mathrm{O}_{4}$ magnetic nanohybrids by a mixed method (coprecipitation synthesis and hydrothermal method) within the range of $10-15 \mathrm{~nm}$ for magnetic hyperthermia and delivery of Doxorubicin to cancer cells (HeLa cells) [39]. They showed that Doxorubicin was successfully loaded into the nanohybrids (drug-loading efficiency; $\sim 99 \%$ ) and released by $\mathrm{pH}$ dependent manner. The concentration of $0.94 \mathrm{mg} / \mathrm{ml}(\mathrm{R} 2=0.957)$ Dox-loaded nanocomposites decreased the viable cell population by $50 \%$ and prevented their proliferation [40]. In another study, $\mathrm{Fe}_{3} \mathrm{O}_{4} @ \mathrm{MTX}-\mathrm{LDH} / \mathrm{Au}$ nanoparticles were developed by Zhao et al. through coprecipitation electrostatic interaction strategy to deliver the anticancer drug of methotrexate (MTX). Likewise, the cumulative percent of the prepared sample and some previously reported materials for Diclofenac and Ibuprofen are compared in Table 1.

\section{Conclusion}

In this research, $\mathrm{Fe}_{3} \mathrm{O}_{4} @ \mathrm{LDH}$ multicore-shell nanostructure was synthesized through the coprecipitation experiment and used as a new drug nanocarrier. Antimicrobial activity of three important pathogenic bacteria were tested. $\mathrm{Fe}_{3} \mathrm{O}_{4} @ \mathrm{LDH}$ can inhibit the growth of two strains of examined bacteria. This antibacterial property may be due to disruption of bacterial membranes and the hindrance of biofilm formation. Furthermore, nanostructure

Table 1 Comparison of different nanocarriers for Diclofenac sodium and Ibuprofen

\begin{tabular}{|c|c|c|c|c|c|c|}
\hline Nanocarrier & Drug & $\begin{array}{l}\text { Max. } \\
\text { release (\%) }\end{array}$ & Max. time & $\mathrm{pH}$ & Particle size & Refs. \\
\hline Zn-Al layered double hydroxide (LDH) & Diclofenac sodium & 80 & $60 \mathrm{~h}$ & 7.4 & $632.6 \mathrm{~nm}$ & {$[41]$} \\
\hline Sodium alginate/layered double hydroxides & Diclofenac sodium & 99 & $8 \mathrm{~h}$ & 7.4 & ND & {$[42]$} \\
\hline Ca-Al layered double hydroxide & Diclofenac sodium & 84 & $400 \mathrm{~min}$ & 4.6 & $1-3 \mu \mathrm{m}$ & {$[43]$} \\
\hline $\mathrm{Zn}-\mathrm{Al}-\mathrm{NO}_{3}$-layered double hydroxides & Diclofenac sodium & 98.4 & $6 \mathrm{~h}$ & 6.8 & $132 \pm 9 \mathrm{~nm}$ & [44] \\
\hline IBU-LZH & Ibuprofen & 77 & $1200 \mathrm{~min}$ & 4.8 & $50-100 \mathrm{~nm}$ & [45] \\
\hline Drug-LDH loaded PCL fibers & Ibuprofen & 45 & $120 \mathrm{~h}$ & 7.4 & $147 \pm 37 \mathrm{~nm}$ & [46] \\
\hline Alginate-zein/layered double hydroxide biocomposite & Ibuprofen & 97 & $8 \mathrm{~h}$ & 7.4 & ND & [47] \\
\hline \multirow[t]{2}{*}{ Magnetic@layered double hydroxide } & Diclofenac sodium & 82 & $72 \mathrm{~h}$ & 7.4 & $80-130 \mathrm{~nm}$ & This study \\
\hline & Ibuprofen & 96 & & 7.4 & & \\
\hline
\end{tabular}

ND not detected 
cytotoxicity was examined on $\mathrm{C} 2 \mathrm{C} 12$ myoblast cells via MTT assay analysis. The results revealed that nanostructure in physiological concentration has not cytotoxicity of eukaryotic cells in vitro and can be a good candidate as a nanocarrier for drug delivery in human bodies. Ibuprofen and Diclofenac were selected as the model drugs, being intercalated between LDH nanoflakes to synthesize $\mathrm{Fe}_{3} \mathrm{O}_{4} @ \mathrm{LDH}$-ibuprofen and $\mathrm{Fe}_{3} \mathrm{O}_{4} @ \mathrm{LDH}$-diclofenac. Characterization of the synthesized-nanocarrier was achieved using XRD, FT-IR, SEM, VSM, and TEM for displaying the chemical structure and morphology. The $\mathrm{Fe}_{3} \mathrm{O}_{4} @ L D H$-ibuprofen and $\mathrm{Fe}_{3} \mathrm{O}_{4} @ L D H$-diclofenac were tested for the controlled release of Ibuprofen and Diclofenac under physiological conditions, pH 7.4 (PBS). The above nanostructures also had the advantage of a strong interaction between the carboxyl groups with higher trivalent cations via bridging bidentate, clarity, and high thermal stability. $\mathrm{Fe}_{3} \mathrm{O}_{4} @ \mathrm{LDH}$ multicore-shell nanostructure will possibly have a potential application for constant drug delivery.

\section{Supplementary information}

Supplementary information accompanies this paper at https://doi. org/10.1186/s12951-020-00718-y.

Additional file 1: Figure S1. The standard curve of Ibuprofen in phosphate buffer, pH 7.4. Figure S2. The standard curve of Diclofenac sodium in phosphate buffer, $\mathrm{pH}$ 7.4. Figure S3. The cumulative release kinetic of Ibuprofen and Diclofenac from $\mathrm{Fe}_{3} \mathrm{O}_{4} @ \mathrm{LDH}$ h hanostructure in phosphate buffer saline (PBS) at $\mathrm{pH}=7.4$.

\section{Acknowledgements}

This study was supported by the Faculty of Pharmacy, Tabriz University of Medical Sciences, and Drug Applied Research Center, Tabriz University of Medical Sciences, Tabriz, Iran.

\section{Authors' contributions}

$V Y$ and $A D$ designed the study and performed the vitro experiments; VT carried out the biological experiments, VY, VT, SE and AD supervised the whole work and wrote the manuscript. All authors read and approved the final manuscript.

\section{Funding}

This work was supported by Tabriz University of Medical Sciences, Tabriz, Iran.

\section{Availability of data and materials}

All data used to generate these results is available in the main text.

\section{Ethics approval and consent to participate}

The study was approved by Ethics Committee of Tabriz University of Medical Sciences, Tabriz, Iran.

\section{Consent for publication}

Not applicable.

\section{Competing interests}

The authors declare that they have no competing interests.

\section{Author details}

${ }^{1}$ Molecular Medicine Research Center, Biomedicine Institute, Tabriz University of Medical Sciences, Tabriz, Iran. ${ }^{2}$ Department of Biotechnology, School of Advanced Technologies in Medicine, Shahid Beheshti University of Medical Sciences, Tehran, Iran. ${ }^{3}$ Drug Applied Research Center, Tabriz University of Medical Sciences, Tabriz, Iran. ${ }^{4}$ Department of Pharmaceutical Biotechnology, Faculty of Pharmacy, Tabriz University of Medical Sciences, Tabriz, Iran.

Received: 7 August 2020 Accepted: 22 October 2020

Published online: 29 October 2020

\section{References}

1. Lauhon LJ, Gudiksen MS, Wang D, Lieber CM. Epitaxial coreshell and core-multishell nanowire heterostructures. Nature. 2002;420(6911):57-61.

2. Fischer S, Mehlenbacher RD, Lay A, Siefe C, Alivisatos AP, Dionne JA. Small alkaline-earth-based core/shell nanoparticles for efficient upconversion. NanoLett. 2019;19(6):3878-85.

3. Yavuz E, Tokalıoğlu Ş, Patat \$̧. Core-shell $\mathrm{Fe}_{3} \mathrm{O}_{4}$ polydopamine nanoparticles as sorbent for magnetic dispersive solid-phase extraction of copper from food samples. Food Chem. 2018;263:232-9.

4. Foroutani R, Yousefi V, Kangari S. Synthesis of polyaniline-magnetite hollow nanocomposite as a novel fiber coating for the headspace solidphase microextraction of benzene, toluene, ethylbenzene and xylenes from water samples. Anal Methods. 2015;7(12):5318-24.

5. Dowaidar M, Nasser Abdelhamid H, Hällbrink M, Langel Ü, Zou X. Chitosan enhances gene delivery of oligonucleotide complexes with magnetic nanoparticles_cell-penetrating peptide. J BiomaterAppl. 2018;33(3):392-401.

6. Gu P, Zhang S, Li X, Wang X, Wen T, Jehan R, et al. Recent advances in layered double hydroxide-based nanomaterials for the removal of radionuclides from aqueous solution. Environ Pollut. 2018:240:493-505.

7. Wang X, Pan F, Xiang Z, Zeng Q, Pei K, Che R, et al. Magnetic vortex core-shell $\mathrm{Fe}_{3} \mathrm{O}_{4} @$ Cnanorings with enhanced microwave absorption performance. Carbon. 2020;157:130-9.

8. Dowaidar M, Abdelhamid HN, Hällbrink M, Freimann K, Kurrikoff K, Zou $X$, et al. Magnetic nanoparticle assisted self-assembly of cell penetrating peptides-oligonucleotides complexes for gene delivery. Sci Rep. 2017;7(1):1-11.

9. Zhang J, Li Z, Chen Y, Gao S, Lou XW. Nickel-iron layered double hydroxide hollow polyhedrons as a superior sulfur host for lithium-sulfur batteries. AngewChemlnt Ed. 2018;57(34):10944-8.

10. Yazdani P, Mansouri E, Eyvazi S, Yousefi V, Kahroba H, Hejazi MS, et al. Layered double hydroxide nanoparticles as an appealing nanoparticle in gene/plasmid and drug delivery system in C2C12 myoblast cells. Artif Cells NanomedBiotechnol. 2019;47(1):436-42.

11. Xiang $Y$, Xiang $Y$, Jiao Y, Wang L. Surfactant-modified magnetic CaFe-layered double hydroxide for improving enzymatic saccharification and ethanol production of Artemisia ordosica. Renew Energy. 2019;138:465-73.

12. Xu ZP, Lu GM. Layered double hydroxide nanomaterials as potential celIular drug delivery agents. Pure ApplChem. 2006;78(9):1771-9.

13. Rojas R, Palena M, Jimenez-Kairuz A, Manzo R, Giacomelli C. Modeling drug release from a layered double hydroxide-ibuprofen complex. Appl Clay Sci. 2012;62:15-20.

14. Mohanty DP, Palve YP, Sahoo D, Nayak P. Synthesis and characterization of chitosan/cloisite 30B (MMT) nanocomposite for controlled release of anticancer drug curcumin. Int J Pharm Res Allied Sci. 2012;1 (4):52-62.

15. Kura AU, Hussein MZ, Fakurazi S, Arulselvan P. Layered double hydroxide nanocomposite for drug delivery systems; bio-distribution, toxicity and drug activity enhancement. Chem Cent J. 2014;8(1):47.

16. Ladewig K, Niebert M, Xu ZP, Gray PP, Lu GQM. Controlled preparation of layered double hydroxide nanoparticles and their application as gene delivery vehicles. Appl Clay Sci. 2010;48(1-2):280-9.

17. Tyner KM, Schiffman SR, Giannelis EP. Nanobiohybrids as delivery vehicles for camptothecin. J Control Release. 2004;95(3):501-14.

18. Mansouri E, Tarhriz V, Yousefi V, Dilmaghani A. Intercalation and release of an anti-inflammatory drug into designed three-dimensionally layered double hydroxide nanostructure via calcination-reconstruction route. Adsorption. 2020. https://doi.org/10.1007/s10450-020-00217-4. 
19. Tarhriz V, Eyvazi S, Shakeri E, Hejazi MS, Dilmaghani A. Antibacterial and antifungal activity of novel freshwater bacterium Tabrizicola aquatica as a prominent natural antibiotic available in Qurugol Lake. Pharm Sci. 2020;26(1):88-92.

20. Tarhriz V, Eyvazi S, Musavi M, Abasi M, Sharifi K, Ghanbarian H, et al. Transient induction of C $\mathrm{dk} 9$ in the early stage of differentiation is critical for myogenesis. J Cell Biochem. 2019;120(11):18854-61.

21. Huang $W$, Wang $Y$, Wei $S$, Wang $B$, Liang $Y$, Huang $Y$, et al. Effect of reaction time on microwave absorption properties of $\mathrm{Fe}_{3} \mathrm{O}_{4}$ hollow spheres synthesized via Ostwald ripening. Materials. 2019;12(18):2921.

22. Karaoğlu E, Baykal A, Şenel M, Sözeri H, Toprak MS. Synthesis and characterization of piperidine-4-carboxylic acid functionalized $\mathrm{Fe}_{3} \mathrm{O}_{4}$ nanoparticles as a magnetic catalyst for Knoevenagel reaction. Mater Res Bull. 2012;47(9):2480-6.

23. Ozel F, Kockar H, Beyaz S, Karaagac O, Tanrisever T. Superparamagnetic iron oxide nanoparticles: effect of iron oleate precursors obtained with a simple way. J Mater Sci Mater Electron. 2013;24(8):3073-80.

24. Wang L, Hu C, Shao L. The antimicrobial activity of nanoparticles: present situation and prospects for the future. Int J Nanomed. 2017;12:1227.

25. Oh J-M, Choi S-J, Kim S-T, Choy J-H. Cellular uptake mechanism of an inorganic nanovehicle and its drug conjugates: enhanced efficacy due to clathrin-mediated endocytosis. BioconjugChem. 2006;17(6):1411-7.

26. Jin W, Park D-H. Functional layered double hydroxide nanohybrids for biomedical imaging. Nanomaterials. 2019;9(10):1404.

27. Gao W, Chan JM, Farokhzad OC. pH-responsive nanoparticles for drug delivery. Mol Pharm. 2010;7(6):1913-20.

28. Prasanna S, Kamath PV. Anion-exchange reactions of layered double hydroxides: interplay between coulombic and $\mathrm{H}$-bonding interactions. IndEngChem Res. 2009;48(13):6315-20.

29. Zhang Y, Evans JR. Alignment of layered double hydroxide platelets. Colloids Surf A. 2012:408:71-8.

30. Yan L-G, Yang K, Shan R-R, Yu H-Q, Du B. CalcinedZnAl- and $\mathrm{Fe}_{3} \mathrm{O}_{4} / \mathrm{ZnAl}$ layered double hydroxides for efficient removal of $\mathrm{Cr}(\mathrm{VI})$ from aqueous solution. RSC Adv. 2015;5(117):96495-503.

31. Fini A, Bassini G, Monastero A, Cavallari C. Diclofenac salts, VIII. Effect of the counterions on the permeation through porcine membrane from aqueous saturated solutions. Pharmaceutics. 2012;4(3):413-29.

32. Schettler T, Paris S, Pellett M, Kidner S, Wilkinson D. Comparative pharmacokinetics of two fast-dissolving oral ibuprofen formulations and a regular-release ibuprofen tablet in healthy volunteers. Clin Drug Investig. 2001;21(1):73-8

33. Shaw LR, Irwin WJ, Grattan TJ, Conway BR. The effect of selected watersoluble excipients on the dissolution of paracetamol and ibuprofen. Drug Dev Ind Pharm. 2005:31(6):515-25.
34. Madikizela LM, Chimuka L. Simultaneous determination of naproxen, ibuprofen and diclofenac in wastewater using solid-phase extraction with high performance liquid chromatography. Water Sa. 2017;43(2):264-74.

35. Czyrski A. Determination of the lipophilicity of ibuprofen, naproxen, ketoprofen, and flurbiprofen with thin-layer chromatography. J Chem. 2019. https://doi.org/10.1155/2019/3407091.

36. Bhadra BN, Ahmed I, Kim S, Jhung SH. Adsorptive removal of ibuprofen and diclofenac from water using metal-organic framework-derived porous carbon. ChemEng J. 2017;314:50-8.

37. Bi X, Zhang H, Dou L. Layered double hydroxide-based nanocarriers for drug delivery. Pharmaceutics. 2014;6(2):298-332.

38. Prasad $\mathrm{C}$, Tang $\mathrm{H}$, Liu W. Magnetic $\mathrm{Fe}_{3} \mathrm{O}_{4}$ based layered double hydroxides (LDHs) nanocomposites $\left(\mathrm{Fe}_{3} \mathrm{O}_{4} / \mathrm{LDHs}\right)$ : recent review of progress in synthesis, properties and applications. J NanostructChem. 2018;8(4):393-412.

39. Komarala EP, Nigam $S$, Aslam M, Bahadur D. In-vitro evaluation of layered double hydroxide $-\mathrm{Fe}_{3} \mathrm{O}_{4}$ magnetic nanohybrids for thermo-chemotherapy. New J Chem. 2016;40(1):423-33.

40. Shan R-R, Yan L-G, Yang K, Yu S-J, Hao Y-F, Yu H-Q, et al. Magnetic $\mathrm{Fe}_{3} \mathrm{O}_{4} /$ MgAl-LDH composite for effective removal of three red dyes from aqueous solution. ChemEng J. 2014;252:38-46.

41. Joy M, lyengar SJ, Chakraborty J, Ghosh S. Layered double hydroxide using hydrothermal treatment: morphology evolution, intercalation and release kinetics of diclofenac sodium. Front Mater Sci. 2017;11(4):395-408

42. Zhang JP, Wang $Q$, Xie XL, Li X, Wang AQ. Preparation and swelling properties of $\mathrm{pH}$-sensitive sodium alginate/layered double hydroxides hybrid beads for controlled release of diclofenac sodium. J Biomed Mater Res B ApplBiomater. 2010;92(1):205-14.

43. Ma Y, Zhang S, Wang Y, Jiang Z, Fu N, Yang Z, et al. The structure and release kinetics of $\mathrm{Ca}$-Al layered double hydroxide by intercalating with diclofenac sodium. NANO. 2020;15(03):2050028.

44. Cao F, Wang Y, Ping Q, Liao Z. Zn-Al- $\mathrm{NO}_{3}$-layered double hydroxides with intercalated diclofenac for ocular delivery. Int J Pharm. 2011:404(1-2):250-6.

45. Nabipour H, Sadr MH. Layered zinc hydroxide-ibuprofen nanohybrids: synthesis and characterization. Bull Mater Sci. 2015;38(6):1561-7.

46. Gao Y, Teoh TW, Wang Q, Williams GR. Electrospun organic-inorganic nanohybrids as sustained release drug delivery systems. J Mater Chem B. 2017:5(46):9165-74

47. Alcantara A, Aranda P, Darder M, Ruiz-Hitzky E. Bionanocomposites based on alginate-zein/layered double hydroxide materials as drug delivery systems. J Mater Chem. 2010;20(42):9495-504.

\section{Publisher's Note}

Springer Nature remains neutral with regard to jurisdictional claims in published maps and institutional affiliations.
Ready to submit your research? Choose BMC and benefit from:

- fast, convenient online submission

- thorough peer review by experienced researchers in your field

- rapid publication on acceptance

- support for research data, including large and complex data types

- gold Open Access which fosters wider collaboration and increased citations

- maximum visibility for your research: over 100M website views per year

At BMC, research is always in progress.

Learn more biomedcentral.com/submissions 